() Entomologica Fennica. 24 March 2000

\title{
A re-evaluation of five European species of Spilomena with a key to European species and relevance to the fauna of North Europe, espe- cially Finland (Hymenoptera: Pemphredonidae)
}

\author{
Veli V. Vikberg
}

Vikberg, V. V. 2000: A re-evaluation of five European species of Spilomena with a key to European species and relevance to the fauna of North Europe, especially Finland (Hymenoptera: Pemphredonidae). — Entomol. Fennica 10: 35-55.

A critical examination, including the study of type material, resulted in the following taxonomical changes in the sphecid wasp genus Spilomena: S. pulawskii Dollfuss, 1983 is synonymized with $S$. curruca (Dahlbom, 1843). Spilomena differens Blüthgen, 1953 is considered a valid species. S. exspectata Valkeila, 1957 is synonymized with Spilomena beata Blüthgen, 1953. Spilomena valkeilai sp. $n$. is described from southern Finland, Sweden and Norway. The value of the head form as a taxonomic character in Spilomena is pointed out. A key to species of Spilomena of Europe and the Canary Islands is presented. Spilomena beata and $S$. enslini Blüthgen are added to the fauna of Norway. Notes on the distribution of the species in North Europe, especially Finland are given.

Veli V. Vikberg, Liinalammintie 11 as. 6, FIN-14200 Turenki, Finland. E-mail: veli.vikberg@mail.htk.fi

Received 29 December 1998, revised 25 August 1999, accepted 16 September 1999

\section{Introduction}

The Palaearctic species of the sphecid wasp genus Spilomena Shuckard (Pemphredonidae) were largely revised by Blüthgen (1953). Two species, $S$. curruca (Dahlbom, 1843) and $S$. differens Bluithgen, 1953 have a pitted basal fovea of the mesoscutellum. A third species, having the same character, S. pulawskii, was described later on the basis of one male from the Tatra mountains in S. Poland by Dollfuss (1983). In the revision of the W. and C. Palaearctic species of the genus, Dollfuss (1986) synonymized Spilomena curruca and $S$. differens, because the male genitalia showed only one type and he could not separate females from each other. Actually, Dollfuss (1986) did not study the holotype of $S$. differens at all because he thought that the holotype of the species was the "type" of Celia troglodytes (Lind.) o var. $\beta$ Dahlbom, mentioned by Bluithgen (1953) at the beginning of the description of $S$. differens. In 1990 a second male of $S$. pulawskii was found in Swedish Lapland, LU: Kaltisbäcken, Messaure (Nilsson 1992) and also a female in the same province (Jelkajåkkå, Porjus, in 1990). After having found a new character on the posterior mesoscutum, Dollfuss (1996) identified females of S. pulawskii from the mountains of Austria and Poland.

When studying Finnish specimens of Spilomena, I found two species among those identi- 
fied as $S$. curruca (Dahlbom) and/or $S$. differens Blüthgen. Most females identified as $S$. curruca by E. Valkeila resemble $S$. pulawskii according to the characters given by Dollfuss (1996). This led me to examine the types of the species in question and other specimens from North and Central Europe. Later I studied all available specimens of Spilomena from Finnish collections and partly also from Sweden and Norway in order to clarify the distribution of the species in Northern Europe.

\section{Material and methods}

Specimens of Spilomena were studied from the collections of the Zoological Museum, University of Helsinki (ZMH; Dr. A. Albrecht, Ms. N. Laurenne) including coll. W. Hellén, and the Department of Applied Zoology, University of Helsinki (DAZH; Martti Koponen), including coll. Th. Grönblom, V. J. Karvonen, A. K. Merisuo and E. Valkeila and personal collections of Jonny Perkiömäki, Helsinki, Martti Raekunnas, Iittala (MRPC) and Veli Vikberg, Turenki (VVPC). Specimens of Spilomena differens, curruca, pulawskii and beata/exspectata were loaned from the Naturhistoriska Riksmuseet, Stockholm (Dr. L.-Å. Janzon), the Zoological Institute, University of Lund (ZIUL; Dr. R. Danielsson), the Zoological Museum, University of Oslo (Jan E. Raastad), the Norwegian Forest Institute (NISK), Ass, the Zoological Museum, University of Bergen (ZMUB; Lita Greve Jensen), Naturhistorisches Museum, University of Vienna (NHMW; Dr. S. Schödl), and from the personal collections of Johan Abenius, Nynäshamn (JAPC), Sven Hellqvist, Stockholm and Prof. G. Nilsson, Oslo. A large collection of unidentified Norwegian specimens of Spilomena was loaned from Lars Ove Hansen, Oslo. The lectotype of Celia curruca Dahlbom was studied from coll. Dahlbom, Zoological Institute, University of Lund, Sweden, the holotypes of S. differens Blüthgen and S. exspectata Valkeila from the Zoological Museum, University of Helsinki and the holotype of Spilomena pulawskii Dollfuss from the Naturhistorisches Museum, University of Vienna.

The specimens were examined under a Leitz stereomicroscope operated at magnifications of $50 \mathrm{x}$ and $100 \mathrm{x}$. The light source was a halogen lamp of $12 \mathrm{~V} 20 \mathrm{~W}$ with a narrow light beam of $10^{\circ}$. The light beam was diffused by placing a piece of thick $(0.2 \mathrm{~mm})$ tracing acetate near $(2-15 \mathrm{~mm})$ the specimen (see Goulet \& Huber (1993: 60). Measurements and drawings were made by using a grid of squares $(50 \times 50$, side of a square $0.2 \mathrm{~mm}$ ) in one of the oculars. Measurements were carried out using magnification 100x (ocular $12.5 \mathrm{x}$, objective $8 \mathrm{x}$ ); one side of the ocular square corresponded to $25.3 \mu \mathrm{m}$ in the object, the decimal was estimated by eye.

Besides the POL/OOL index, I measured POL/HW (head width including compound eyes) index. The reasons were the following: the species $S$. curruca and $S$. differens differ mainly by their length of POL (wider in $S$. curruca). The size of the specimen is taken into consideration by measur- ing the width of the head which can be measured relatively more accurately than OOL and without further adjustment of the specimen, only by focusing of the microscope. When the POL was measured, the light came from an anterior direction and a little above; strong, soft light is needed to see the inner margins of the lateral ocelli accurately.

In Spilomena beata and S. valkeilai sp. n. HW/HH, HW/ $\mathrm{FH}$ and $\mathrm{FW} / \mathrm{FH}$ indexes were used. $\mathrm{HH}$ (head height) was measured in anterior or lateral view as a distance of the topmost vertex and apicalmost anterior margin of the clypeus. FH (Face height) was measured in the anterior view as the distance between anterior margin of the median ocellus and apicalmost anterior margin of the clypeus. FW (Face width) was measured as the maximum width between the compound eyes.

\section{Results}

3.1. Spilomena curruca (Dahlbom, 1843) $=S$.
pulawskii Dollfuss, 1983 , syn. nov. Spilomena
differens Blüthgen, 1953 is a valid species

Spilomena curruca and $S$. differens were separated by Blüthgen (1953) based on several characters, e.g. the head behind the eyes is longer and less narrow in $S$. curruca and $\mathrm{OOL}=2 \mathrm{x}$ POL in $S$. curruca, 21/2x POL in $S$. differens. Valkeila (1957) used the same characters. Lomholdt (1975) used the head form and wrote that the ocelli form an obtuse angle in $S$. curruca, an acute angle in $S$. differens. Dollfuss (1986) could not separate the females and synonymized the species, he measured OOL $=2.0-2.5 \mathrm{x}$ POL (seldom 1.6-2.7x POL; $n=113$ ).

Later Dollfuss (1996) found one new character to separate the female of $S$. pulawskii from $S$. "curruca" (actually $S$. pulawskii is a synonym of $S$. curruca (Dahlbom) and his $S$. "curruca" is $S$. differens). The hind margin of the mesoscutum of $S$. pulawskii has few, but strong longitudinal striae, that of $S$. "curruca" many, fine longitudinal striae; the figures referred to in the text were missing. Specimens of Spilomena are small, 2-3 mm long, and sometimes pinned so that it is impossible to see this thoracic character without first relaxing the specimen and taking the pin away. Therefore, further characters in other parts of the body are needed.

The length of POL appeared to be larger in pulawskii-type specimens. In a pilot study I measured POL in Finnish females with pulawskii-type 
mesoscutum (Fig. 1) and the $S$. differens -type mesoscutum (Fig. 2) and counted the POL/HW index with the following result:

pulawskii-type female: POL 94-121 $\mu \mathrm{m}$; POL/ HW mean 0.127, range 0.114-0.143 $(n=24)$;

differens-type female: POL 76-94 $\mu \mathrm{m}$; POL/ HW mean 0.098, range 0.091-0.115 $(n=32)$.

Because the pilot study gave a positive result, a larger number of specimens from a wider geographic area was measured just like the POL/OOL index from the same specimens, and the types of the species were studied.

The lectotype of Celia curruca Dahlbom, 1843 is a female from Norway, Nord-Trøndelag (NTi): Levanger, Thynæss, 2.7.1840, designated by Blüthgen (1953). The locality is ca. $60 \mathrm{~km} \mathrm{NE}$ of Trondheim. The specimen is pinned so that without relaxing it, it is not possible to study the hind margin of its mesoscutum. POL is 4.7 units $=119$ $\mu \mathrm{m}, \mathrm{POL} / \mathrm{OOL}$ 0.59, POL/HW 0.126 (= near the mean of pulawskii-type). Hairs on upper frons long (ad $38 \mu \mathrm{m}$ ), shagreened sculpture on frons strong and extending to median ocellus; temple behind eye strongly developed; clypeus with longitudinal furrow broadening anteriorly fovea-like. Tergum 2 posteromedially without surface sculpture, apical part of last tergum intensively reddish, all characters as in typical pulawskii-type specimens.

The holotype of Spilomena pulawskii Dollfuss, 1983 is a male from Poland, Tatra National Park, Dolina ku Dziurze, 900-950 m, 6.7.1972, leg. M. Fischer. POL is 3.0 units $=76 \mu \mathrm{m}$, POL/OOL 0.48, POL/HW 0.093. All these measurements fit $S$. differens, but other characters (the more extensive whitish colouration on clypeus and lateral face; few coarse, parallel striae on posterior mesonotum and structure of genitalia) are as in typical males of $S$. curruca, so POL is abnormally narrow in the type specimen.

The holotype of Spilomena differens Blüthgen, 1953 is a female from Finland, [Regio aboensis = Ab], Nystad, leg. Hellén, 911 [pale red label, over the number with a red ascending line], Spilomena differens n. sp. क det. Blüthgen 1952 [and on underside] Holotypus. According to the notes of W. Hellén the locality is Uusikaupunki, the island of Hanko (Grid $27^{\circ} \mathrm{E} 6755: 192$ ) and the date is 29.8 .1923 . The hind part of the mes- oscutum of the holotype is drawn in Fig. 2 and POL is 3.0 units $=76 \mu \mathrm{m}$ while $\mathrm{POL} / \mathrm{HW}$ index is 0.093 . Thus $S$. differens is not a synonym of $S$. curruca, but represents a valid species.

An evaluation of the characters which can be used to separate Spilomena curruca and S. differens from each other (based mainly on North European and Austrian specimens, best characters mentioned first):

- microsculpture of posterior mesoscutum (see Figs. 1 and 2). This is a very useful character if posterior mesoscutum can be studied. Usually the striae of $S$. curruca are few and strong but I have seen three females with fine striae from E. Finland (provinces $\mathrm{Sa}$ and $\mathrm{Kb}$ ). However, the lateral striae in $S$. differens are directed distinctly outwards, in $S$. curruca they are longitudinal or even converge in anterior direction, as also in those three aberrant females.

- POL is wider in $S$. curruca than in S. differens. Most specimens can be separated by measuring the POL. From Fig. 5 we can see that if the POL of a female is $96 \mu \mathrm{m}$ or larger, the specimen is $S$. curruca; if the POL is $86 \mu \mathrm{m}$ or smaller, it is $S$. differens. Specimens with POL between these values can be either species.

Usually POL is correlated with OOL; from values in Blüthgen (1953) and Valkeila (1957) it can be counted that POL/OOL is 0.5 in $S$. curru$c a$ and 0.4 in $S$. differens but these authors did not say how many specimens were measured and of S. curruca they had few females. Dollfuss (1986) measured 113 females of combined S. curruca and $S$. differens and the extreme values were 0.63 and 0.37 [ 0.37 was based obviously on a specimen of S. enslini, see 3.5.1].

I measured POL/OOL and POL/HW indices in 51 females of $S$. curruca and 76 females of $S$. differens from Austria, Finland, Norway, Poland and Sweden. The results are shown in Figs. 5-6 and Table 1 . In order to separate $S$. curruca and $S$. differens from each other the two indices POL/ OOL and POL/HW appear to be equal, because the values of OOL and HW are nearly the same in both species. (But for instance in order to separate $S$. troglodytes and S. enslini from each other POL/OOL is better than POL/HW, because in $S$. enslini POL is smaller and OOL is larger than in S. troglodytes.) 


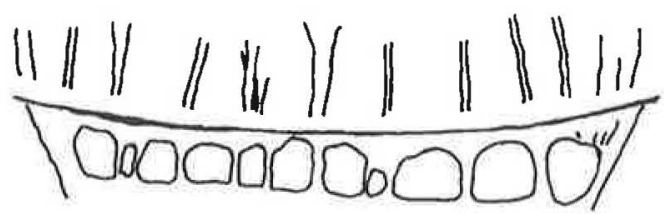

1

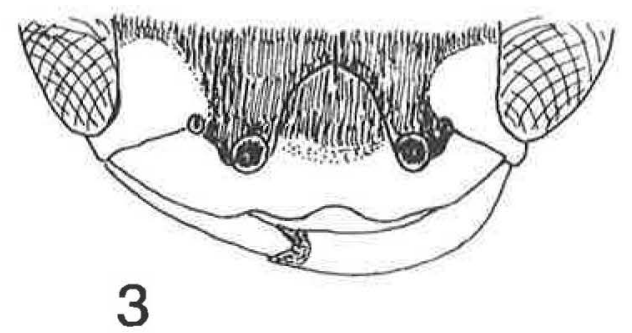

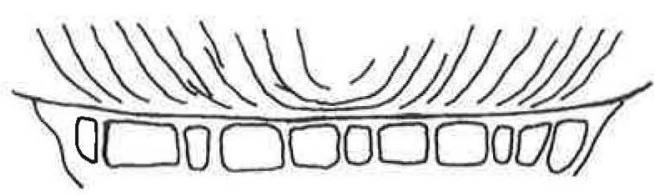

2

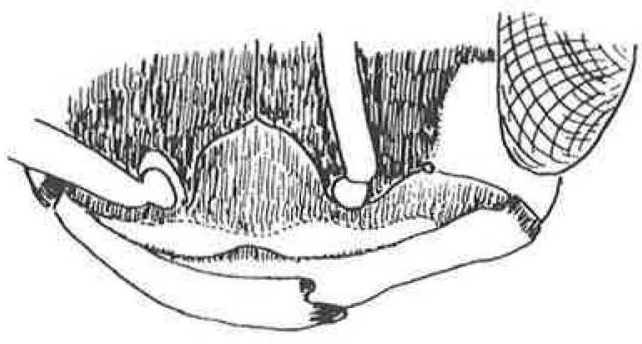

4

Figs. 1-4. Figs. 1-2. Posterior margin of mesoscutum and base of mesoscutellum of the female, 1. Spilomena curruca (Dahlbom), Janakkala, Tuulensuu; 2. Spilomena differens Blüthgen, the holotype. Scale bar 0.05 mm; Figs. 3-4. Lower part of male head to show area of pale colouration; 3. Spilomena curruca (Dahlbom), Janakkala, Tuulensuu; 4. Spilomena differens Blüthgen, Janakkala, Tuulensuu. Scale bar $0.1 \mathrm{~mm}$.

The POL/OOL measurements in males of $S$. curruca and S. differens are shown in Fig. 7. Males are usually smaller than females and their values of POL are smaller (in $S$. curruca $76-91 \mu \mathrm{m}$, in $S$. differens 63-86 $\mu \mathrm{m}$. All known males of $S$. curruca $(n=6)$ were measured and they have higher POL/OOL value $(0.55$ or more) than males of $S$. differens ( 0.52 or less); the only exception is the holotype of S. pulawskii (POL/OOL 0.48). Three males of $S$. curruca were from Austria and they had been identified by Dollfuss in 1996 as $S$. pulawskii although they are not mentioned in his paper (Dollfuss 1996).

- The males of the two species differ in addition by the pale colouration of the clypeus and the lateral face, which is clearly more extensive in S. curruca (Fig. 3) than in S. differens (Fig. 4). The male termed $S$. curruca in Lomholdt (1975, fig. 172) was in reality also a male of $S$. differens.

- The male genitalia were studied by Dollfuss (1983) and are diagnostic. The genitalia of S. curruca were figured under the new species $S$. pu- lawskii.

- female: hairs on the upper frons are longer in S. curruca (Lomholdt 1975). This is a useful additional character, longest hairs in $S$. curruca are usually $25 \mu \mathrm{m}$ or longer, in many specimens of $S$. differens hairs are much shorter.

- female: head behind eyes in dorsal view is longer, more weakly narrowed posteriorly and temple behind eye in lateral view is longer in $S$. curruca. However, some small specimens hardly differ from $S$. differens.

- female: shagreened microsculpture on frons is stronger and weakening less near median ocellus in $S$. curruca, weaker and especially weak or missing near median ocellus in $S$. differens.

- female: longitudinal furrow of clypeus is stronger and widening apically fovea-like in $S$. curruca, weaker, narrow or missing in $S$. differens.

- female: tergum 2 posteromedially smooth or with faint surface sculpture (S. curruca), with distinct alutaceous sculpture (S. differens) 


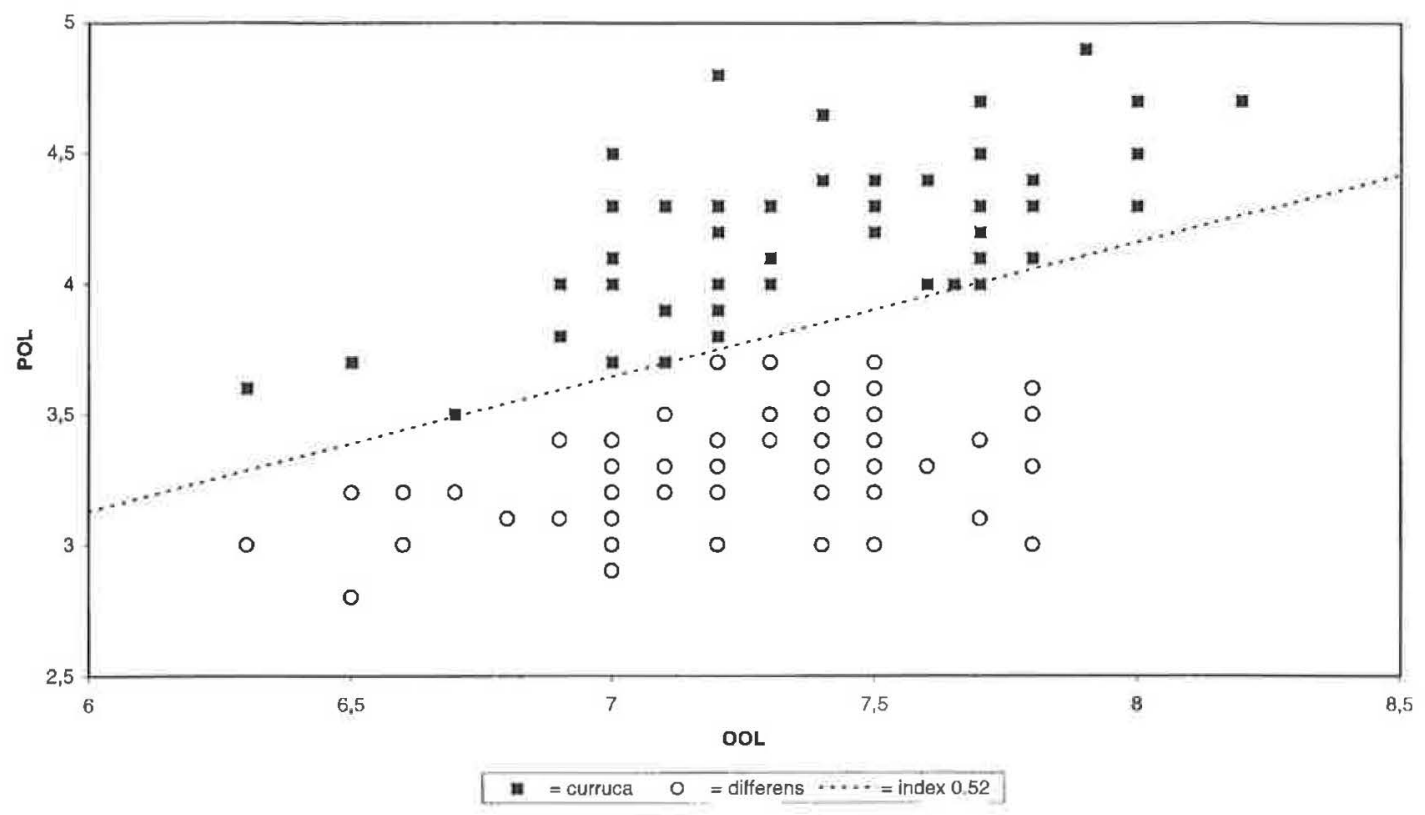

Fig. 5. Measurements of postocellar line (POL) and ocular-ocellar line (OOL) in females of Spilomena curruca (Dahlbom) and $S$. differens Blüthgen. One unit $=25.3 \mu \mathrm{m}$.

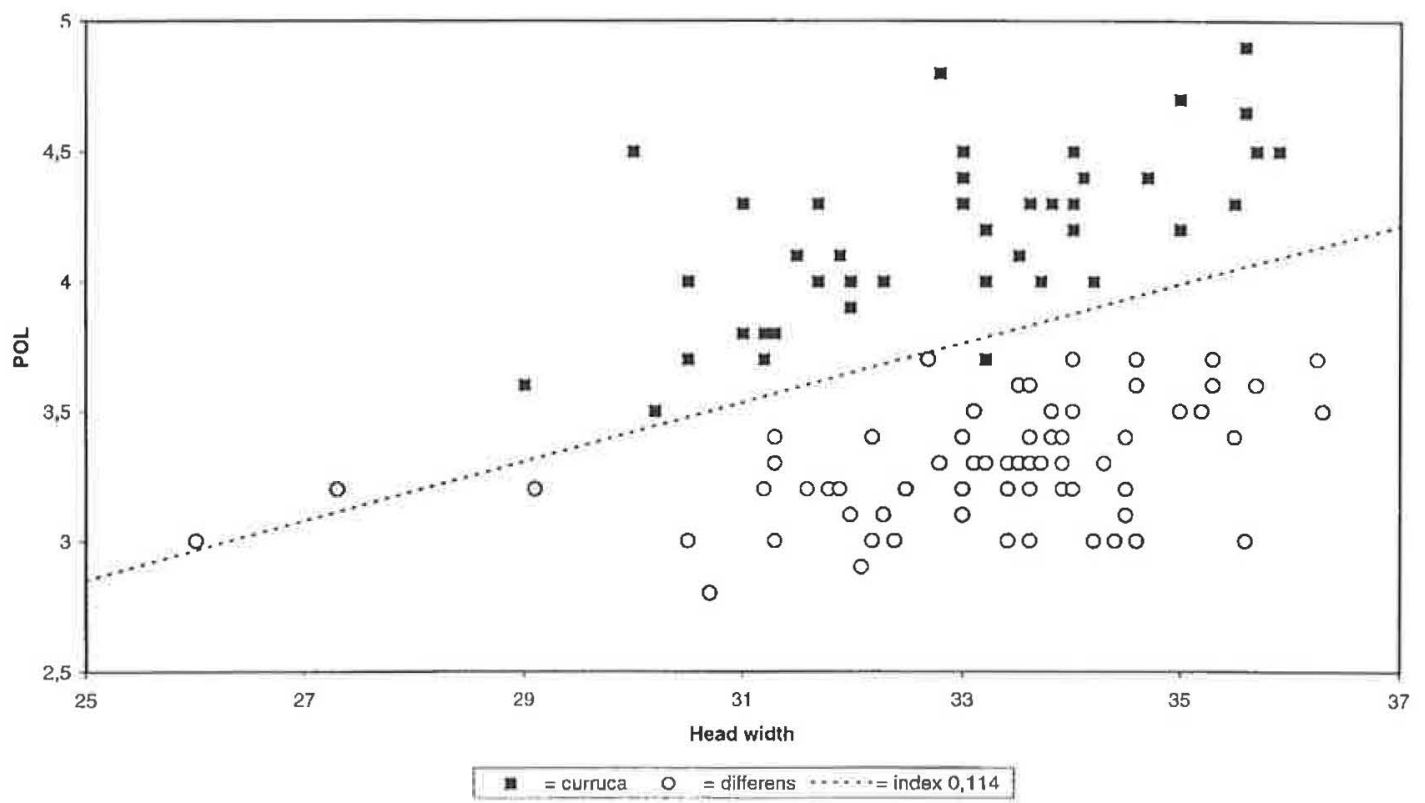

Fig. 6. Measurements of postocellar line (POL) and head width (HW) in females of Spilomena curruca (Dahlbom) and $S$. differens Blüthgen. One unit $=25.3 \mu \mathrm{m}$. 
Table 1. POL:OOL and POL:HW indices in females of Spilomena curruca (Dahlbom) and S. differens Blüthgen.

\begin{tabular}{|c|c|c|c|c|c|c|c|}
\hline species & country & $n$ & range & mean & S.D. & C.V. & $P$ value \\
\hline & POL:OOL & & & & & & \\
\hline S. curruca & Austria, Poland & 13 & $0.52-0.59$ & 0.558 & 0.022 & 3.9 & \\
\hline S. curruca & Finland & 25 & $0.52-0.67$ & 0.574 & 0.035 & 6.1 & \\
\hline S. curruca & Sweden, Norway & 13 & $0.53-0.64$ & 0.568 & 0.037 & 6.5 & \\
\hline S. differens & Austria, Poland & 20 & $0.42-0.51$ & 0.461 & 0.026 & 5.6 & \\
\hline S. differens & Finland & 21 & $0.42-0.51$ & 0.463 & 0.024 & 5.2 & \\
\hline S. differens & Sweden & 34 & $0.38-0.50$ & 0.446 & 0.029 & 6.5 & \\
\hline S. curruca & all & 51 & $0.52-0.67$ & 0.568 & 0.033 & & \\
\hline \multirow[t]{2}{*}{ S. differens } & all & 76 & $0.38-0.51$ & 0.454 & 0.027 & & $<0.001$ \\
\hline & POL:HW & & & & & & \\
\hline S. curruca & Austria, Poland & 13 & $0.111-0.133$ & 0.1242 & 0.0063 & 5.1 & \\
\hline S. curruca & Finland & 25 & $0.117-0.146$ & 0.1280 & 0.0072 & 5.6 & \\
\hline S. curruca & Sweden, Norway & 13 & $0.119-0.150$ & 0.1284 & 0.0085 & 6.6 & \\
\hline S. differens & Austria, Poland & 20 & $0.087-0.113$ & 0.0998 & 0.0068 & 6.8 & \\
\hline S. differens & Finland & 21 & $0.094-0.117$ & 0.1022 & 0.0062 & 6.1 & \\
\hline S. differens & Sweden & 34 & $0.084-0.105$ & 0.0964 & 0.0055 & 5.7 & \\
\hline S. curruca & all & 51 & $0.111-0.150$ & 0.1271 & 0.0073 & & \\
\hline S. differens & all & 76 & $0.084-0.117$ & 0.0989 & 0.0064 & & $<0.001$ \\
\hline
\end{tabular}

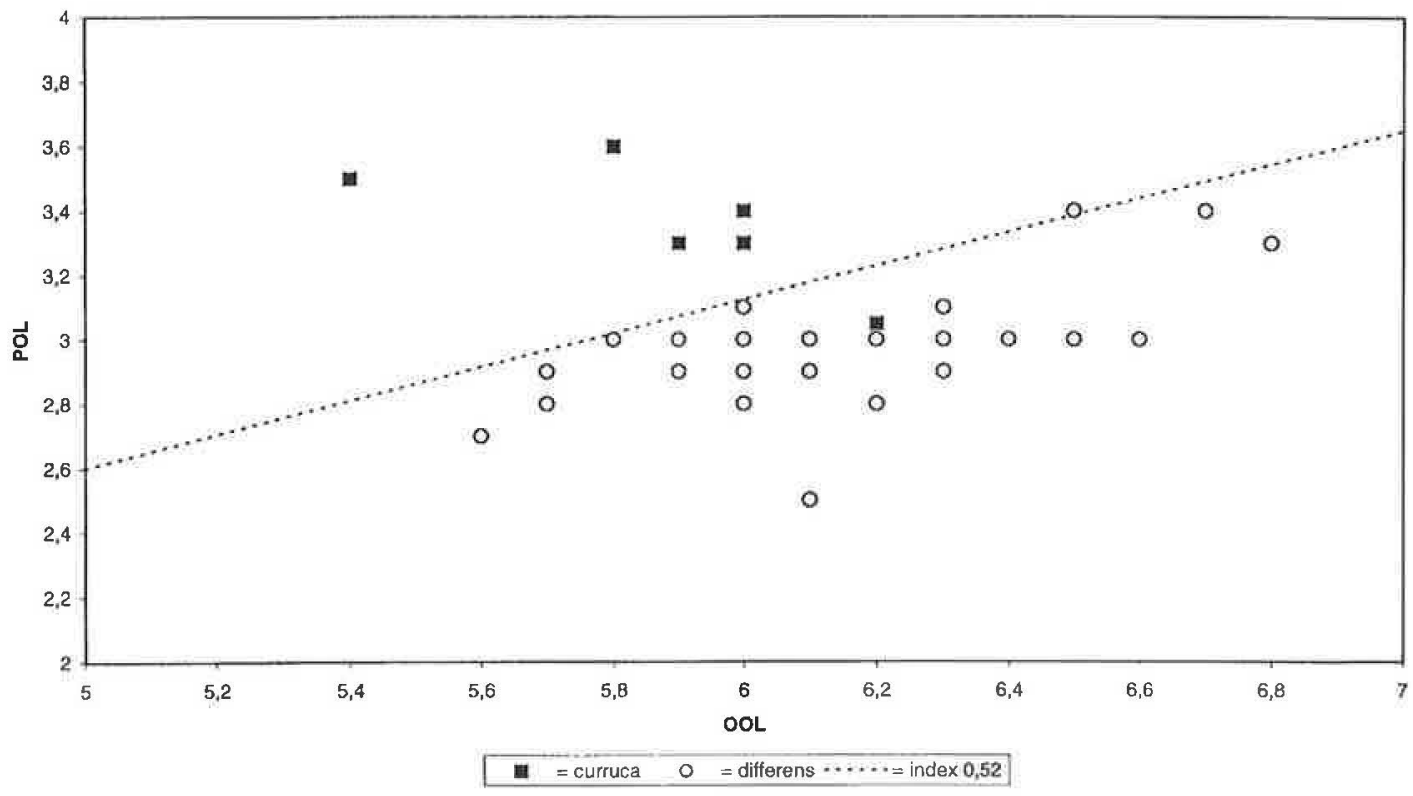

Fig. 7. Measurements of postocellar line (POL) and ocular-ocellar line (OOL) in males of Spilomena curruca (Dahlbom) and $S$. differens Blüthgen. One unit $=25.3 \mu \mathrm{m}$.

- female: the apical part of last tergum (Hellén 1954) is reddish in S. curruca, black in S. differens. Few specimens of $S$. differens are intermediate.

\subsection{Head form as a taxonomic character in Spilomena}

Blüthgen (1953) used "Gesichtsmasse; Länge: Breite" to characterize the head in anterior view. 
Actually he measured head height: head width. The head height was measured from the uppermost medial vertex to the medial apex of the clypeus (if clypeus is incised apicomedially to the base of incision) and the head width as maximal width including eyes. I have counted HW/HH index (female value, male value) from his measurements $(n=1)$ to make them more easily comparable: $S$. mocsaryi $1.05,1.15$; punctatissima $0.98,1.07$; differens -, 1.17; beata 1.07, 1.08; enslini 1.12, 1.16; canariensis -, 1.12; troglodytes $1.12,1.19$; vagans $1.15,1.15$. Males appear to have a slightly higher value of $\mathrm{HW} / \mathrm{HH}$ index. Valkeila (1957) used the same terminology and according to him $\mathrm{HW} / \mathrm{HH}$ is 1.10 in female of $S$. exspectata.

For comparison I measured the HW/HH index in one large female and one large male of each species of Spilomena; the following values were obtained ( $\mathrm{HH}$ was measured from level of apicalmost anterior margin of clypeus, not from medial incision if present): S. mocsaryi 0.97, 1.00; punctatissima $0.95,1.03$; curruca $1.16,1.20$; differens 1.13, 1.15; beata 1.04, 1.06; "exspectata" 1.11, 1.13; enslini 1.09, 1.14; canariensis 1.06, 1.08; troglodytes 1.06, 1.07; "vagans" 1.07, 1.09.

The HW/HH index is smallest in S. mocsaryi and S. punctatissima (narrow, high head) and largest in $S$. curruca (broad head). Males have a slightly higher index. S. beata and S. exspectata auct. appear to differ in head form, in females of these species the head form is the best distinguishing character so far found (see 3.3).

The form of the compound eye varies similarly in species of Spilomena; I measured the height/ width index in one female and one male of each species and got the following result: $S$. mocsary $i$ 2.2, 2.4; punctatissima 2.3, 2.3; curruca 1.9, 1.7; differens 1.9, 1.9; beata 2.0; 1.9; "exspectata" 2.0, 1.7; enslini 2.1, 1.8; canariensis $2.1,1.9$; troglodytes 2.0, 1.9; “vagans" 2.0, 2.0.

3.3. Spilomena beata Blüthgen, $1953=S$. exspectata Valkeila, 1957, syn. n. Description of Spilomena valkeilai sp. $\mathbf{n}$.

Spilomena beata was described from southern France, Haute Garonne, St. Béat (12 females, in- cluding the holotype, and 2 males; leg. Ribaut) and Lèz (1 male) (Blüthgen 1953). S. exspectata was described on the basis of one female (the holotype) from SW. Finland, Ab: Masku and one female paratype from Sweden, Gstr: Hille (Valkeila 1957). Two male paratypes from Sweden were later found to belong to another species (Valkeila 1961). In the same paper Valkeila (1961) first compared $S$. beata and $S$. exspectata and tried to give some differences. He wrote that it is useless to give measurements because the species are so close to each other. In the revision of the genus, Dollfuss (1986) wrote that by external characters the species cannot be distinguished with certainty although the genitalia of the males are distinctly different.

I studied some of the same specimens of $S$. beata mentioned by Valkeila (1961: 143) and compared them with specimens of $S$. "exspectata" from and near Hämeenlinna, Finland. The face of the Finnish specimens appeared to be relatively broader. Therefore I studied more specimens from Austria, Norway and Sweden and measured the HW/HH, HW/FH and FW/FH indices of them. The measurements of HW, $\mathrm{HH}$ and $\mathrm{FH}$ of the females are shown in Figs. 8-9 and Table 2. The Finnish females are smaller, their HW is maximally 32.5 units $=0.82 \mathrm{~mm}$, when compared with specimens from Austria, Sweden and Norway with HW maximum 34.7, 35.5 and 35.7 units $=0.88$, 0.90 and $0.90 \mathrm{~mm}$. In Finnish females HW/HH and HW/FH indices are larger than in other females. The holotype of $S$. exspectata differs from other Finnish females; its HW/HH index 1.06 and HW/FH index 1.26 are similar to Austrian and most Swedish females. A female from the type locality (Saint-Beát, 20.IX.1952, coll. Ribaut) of S. beata was measured and its $\mathrm{HW} / \mathrm{HH}$ was 1.04 and HW/FH 1.22.

The FW/FH index was also slightly higher in Finnish specimens. The measurements of the females are given in Table 2. In Austrian males $(n=8)$ the FW/FH index was 0.82-0.85, in two Finnish males 0.89 . Sometimes it is difficult to measure FW accurately because antennae are near the eye border. Therefore this index was not studied further.

The measurements of $\mathrm{HW}, \mathrm{HH}$ and $\mathrm{FH}$ of the males are shown in Figs. 10-11. Only two males 
of the broader head form are known from Finland and one from Sweden. Their genitalia are similar to each other but different from the geni- talia of $S$. beata. The HW/HH index of these three males was: range 1.14-1.16, mean 1.150, S. D. 0.010 , and $\mathrm{HW} / \mathrm{FH}$ was range $1.36-1.39$, mean

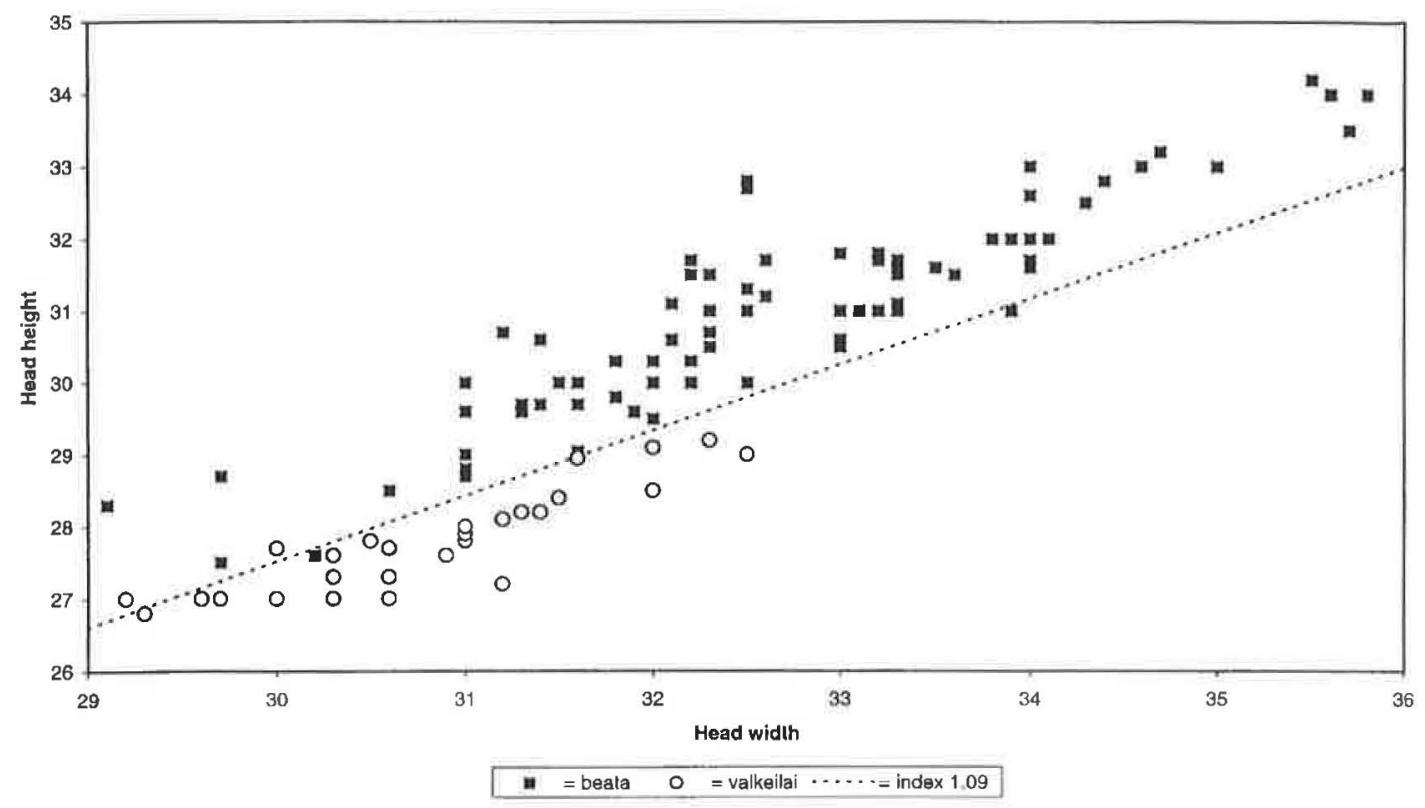

Fig. 8. Measurements of head width $(\mathrm{HW})$ and head height $(\mathrm{HH})$ in females of Spilomena beata Blüthgen and $S$. valkeilai sp. $\mathrm{n}$. One unit $=25.3 \mu \mathrm{m}$.

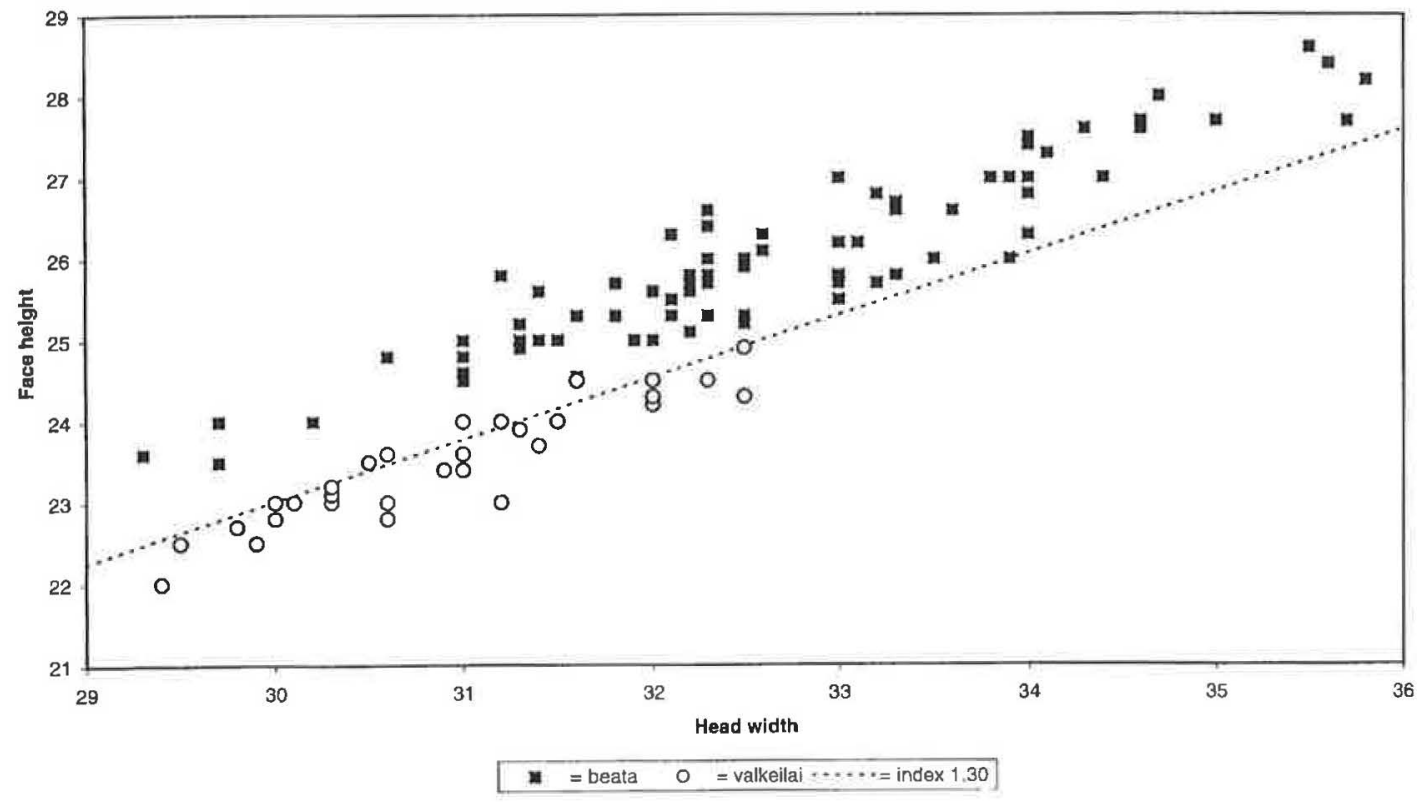

Fig. 9. Measurements of head width $(\mathrm{HW})$ and face height $(\mathrm{FH})$ in females of Spilomena beata Blüthgen and $S$. valkeilai sp. $\mathrm{n}$. One unit $=25.3 \mu \mathrm{m}$. 
Table 2. HW:HH, HW:FH and FW:FH indices in females of Spilomena beata Blüthgen and S. valkeilai sp. $\mathrm{n}$.

\begin{tabular}{|c|c|c|c|c|c|c|c|c|}
\hline index & country & species & $n$ & range & mean & S.D. & C.V. & $P$ value \\
\hline \multirow[t]{6}{*}{$\mathrm{HW}: \mathrm{HH}$} & Austria & S. beata & 22 & $1.03-1.08$ & 1.051 & 0.017 & 1.6 & \\
\hline & Norway & S. beata & 27 & $1.02-1.09$ & 1.062 & 0.016 & 1.5 & \\
\hline & Sweden & S. beata & 31 & $1.03-1.08$ & 1.058 & 0.014 & 1.3 & \\
\hline & Finland & S. valkeilai & 25 & $1.08-1.14$ & 1.110 & 0.013 & 1.2 & \\
\hline & all & S. beata & 81 & $0.99-1.09$ & 1.055 & 0.020 & & \\
\hline & all & S. valkeilai & 29 & $1.08-1.15$ & 1.109 & 0.014 & & $<0.001$ \\
\hline \multirow[t]{6}{*}{$\mathrm{HW}: \mathrm{FH}$} & Austria & S. beata & 22 & $1.21-1.29$ & 1.254 & 0.020 & 1.6 & \\
\hline & Norway & S. beata & 27 & $1.22-1.30$ & 1.259 & 0.019 & 1.5 & \\
\hline & Sweden & S. beata & 31 & $1.23-1.32$ & 1.259 & 0.020 & 1.6 & \\
\hline & Finland & S. valkeilai & 25 & $1.29-1.35$ & 1.316 & 0.015 & 1.1 & \\
\hline & all & S. beata & 85 & $1.21-1.30$ & 1.256 & 0.019 & & \\
\hline & all & S. valkeilai & 29 & $1.29-1.36$ & 1.316 & 0.015 & & $<0.001$ \\
\hline \multirow[t]{2}{*}{ FW:FH } & Austria & S. beata & 22 & $0.83-0.88$ & 0.854 & 0.016 & 1.9 & \\
\hline & Finland & S. valkeilai & 20 & $0.91-0.95$ & 0.921 & 0.017 & 1.8 & \\
\hline
\end{tabular}

\subsection{7, S. D. 0.015 .}

All other males whose genitalia were examined from Austria, Germany, Sweden and Norway belonged to $S$. beata. Two males (Sweden, Gstr: Hille, Forsby, 30.7.1959 and 11.7.1960, leg. $\mathrm{Kj}$. Fahlander) were from the same locality the female paratype of $S$. exspectata was found, the collector being also the same. 22 males of $S$. beata (Austria 7, Germany 2, Norway 4 and Sweden 9 ) were measured and their $\mathrm{HW} / \mathrm{HH}$ index was: range 1.05-1.11, mean 1.085, S. D. 0.018 and HW/ FH: range 1.26-1.36, mean $1.316, S . D .0 .032$.

Specimens from Sweden and Finland termed S. exppectata which Valkeila (1961) used for comparison with Central European specimens of $S$. beata, formed a mixed series. Most of them were $S$. beata (syn. S. exspectata), only two females from Finland, Hämeenlinna represented another species without a valid name. The genitalia of this species were described under $S$. exspectata by Dollfuss (1983). The description of a male of $S$. exspectata in Dollfuss (1986) was based on the same specimen, but the description of the female was based on the holotype of $S$. exspectata and old Swedish specimens which most probably represented $S$. beata. At the beginning of the description of $S$. exspectata Dollfuss wrote that the description is according to Valkeila (1961).

The Finnish specimens with broader head form and different genitalia are described below as a new species. I name it as $S$. valkeilai according to Erkki Valkeila who has captured most of the specimens and also reared the holotype from a nest in the stem of Rubus idaeus $\mathrm{L}$.

\section{Spilomena valkeilai sp. $\mathbf{n}$.}

Female. Length of body ca. 2.5-2.8 mm. Length of fore wing 2.05-2.25 mm. Black. Mandibles dark brown. Scape dark brown, flagellum blackish. Humeral tubercle dark brown or blackish, tegula dark brown. Wing venation brown, wing stigma dark brown. Coxae blackish or dark brown, femora dark brown or blackish. Fore tibiae yellowish brown, mid tibiae slightly, hind tibiae strongly infuscate.

Clypeus apically without or with a very slight emargination. Frons with dense shagreened microsculpture, punctures weak. POL 96-121 $\mu \mathrm{m}$, POL/OOL 0.58-0.73 ( $n=10)$. Mesonotum with dense shagreened microsculpture, posteriorly without striae. Mesoscutellum with dense sculpture, basal fovea short, a little irregular. Dorsal area of propodeum sharply margined laterally and posteriorly, almost smooth, microsculpture nearly wanting; keels variably (often strongly) developed. Tergum 1 smooth, tergum 2 smooth or with faint alutaceous sculpture, tergum 3 and on with 


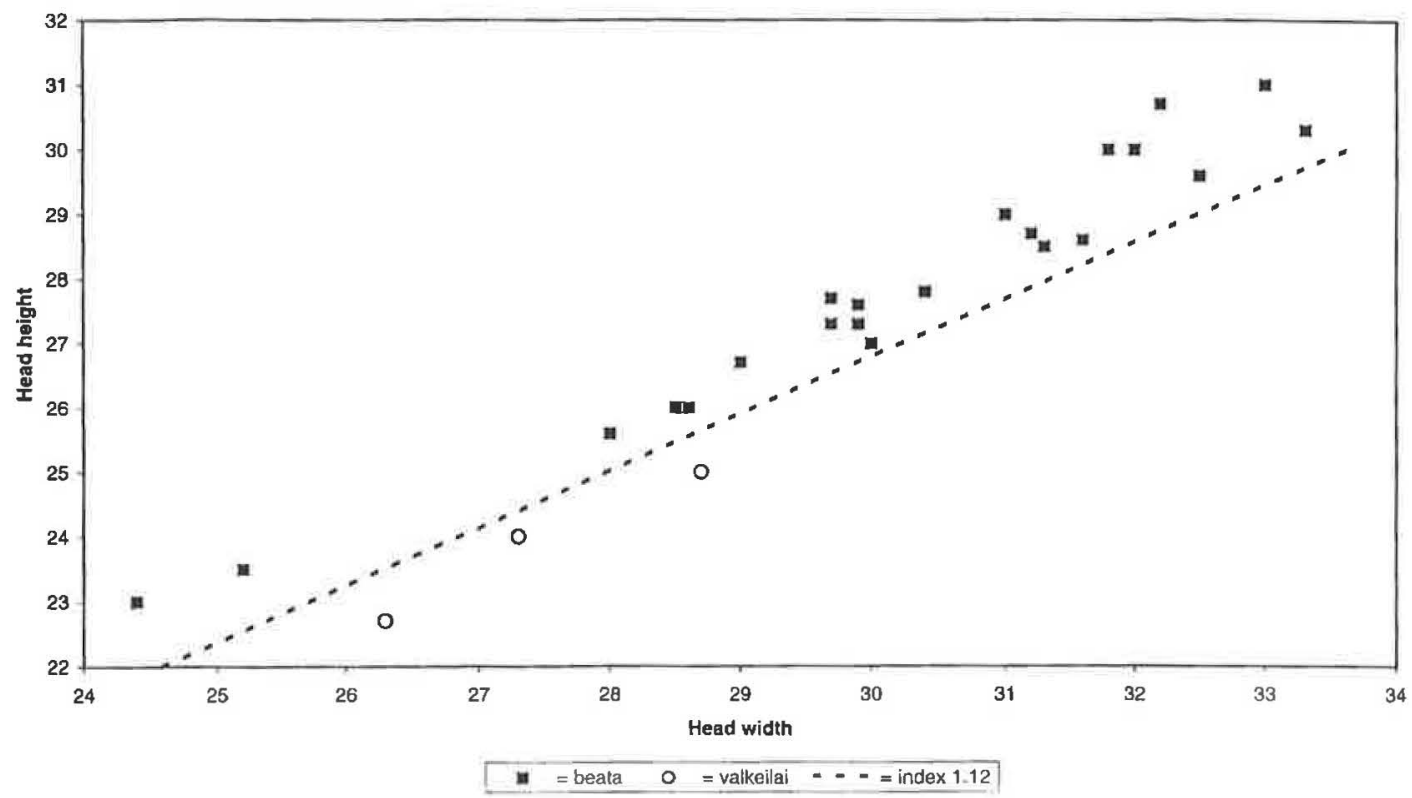

Fig. 10. Measurements of head width $(\mathrm{HW})$ and head height $(\mathrm{HH})$ in males of Spilomena beata Blüthgen and $S$. valkeilai sp. $\mathrm{n}$. One unit $=25.3 \mu \mathrm{m}$.

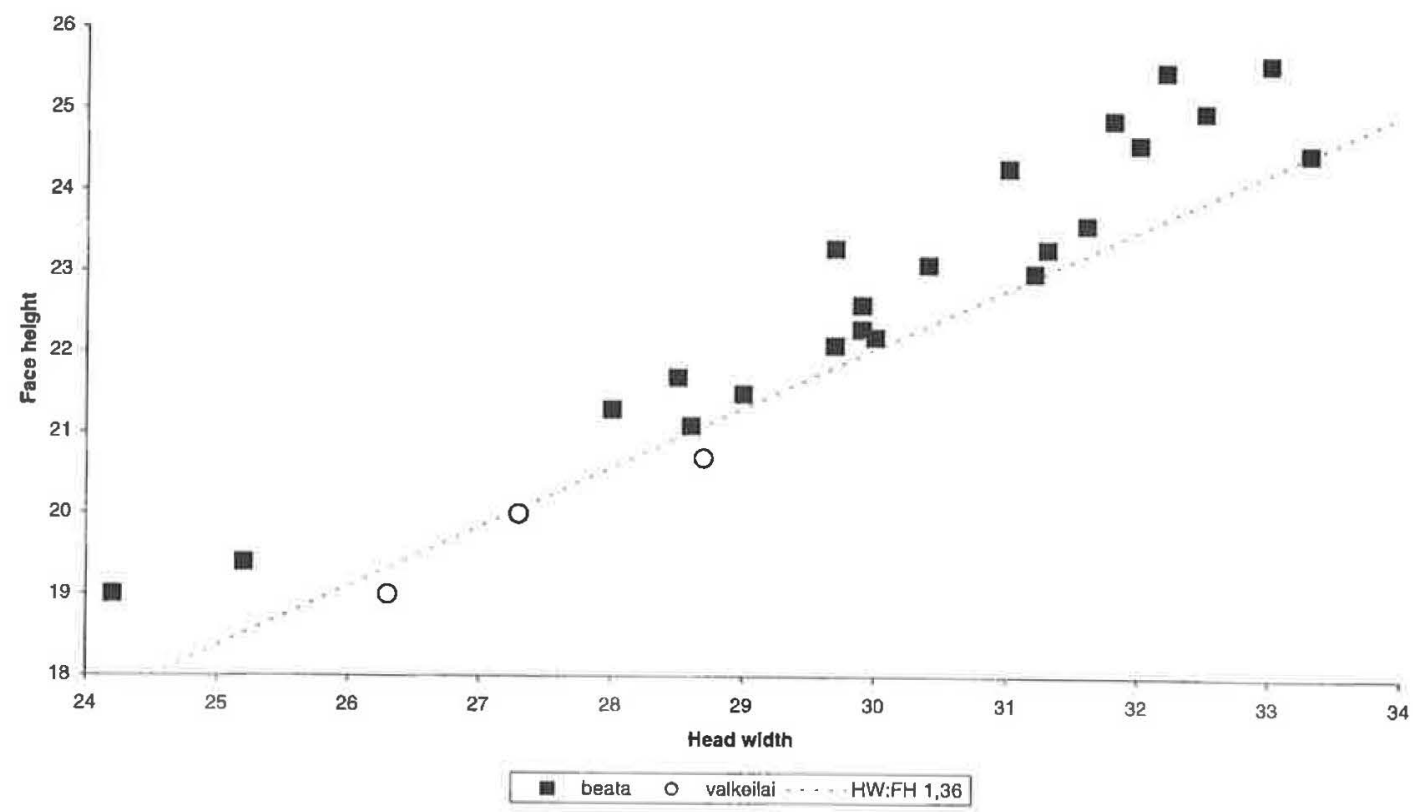

Fig. 11. Measurements of head width $(\mathrm{HW})$ and face height $(\mathrm{FH})$ in males of Spilomena beata Blüthgen and $S$. valkeilai sp. $\mathrm{n}$. One unit $=25.3 \mu \mathrm{m}$. 
dense alutaceous sculpture. Last tergum without keels, apically with two dense tufts of minute whitish setae.

Male. Length of body ca. 2.3-2.5 mm. Length of fore wing 1.75 (holotype)-1.95 mm. Black. Mandibles, clypeus, lateral face, malar space and small area behind base of mandible pale yellow. Scape anteriorly yellow, above slightly brownish. Flagellum above brown, below pale brownish. Humeral tubercle with narrow, yellowish pale margin. Tegula brown. Fore coxa brownish yellow, fore trochanter yellow. Mid and hind coxae dark brownish. Femora brownish black, anterior surface of fore femur yellow. Tibiae yellowish, hind tibiae slightly infuscate. Tarsi yellowish, 1-2 apical tarsomeres infuscate.

Clypeal margin rounded, without emargination. Flagellomeres linear. Frons with dense shagreened microsculpture. POL 89-94 $\mu \mathrm{m}$, POL/ OOL 0.66-0.71 $(n=3)$. Mesoscutum with dense shagreened microsculpture, as well as mesoscutellum. Mesotibial spur short, small. Dorsal surface of propodeum margined laterally and posteriorly, keels rather weak, microsculpture present anteriorly but rather weak. Tergum 1 smooth, tergum 2 with weak alutaceous microsculpture, tergum 3 and following terga with dense microsculpture. Penis valve ca. $0.25 \mathrm{~mm}$ long, with truncate or slightly rounded apex (Fig. 12).
Holotype (male). Finland, Ta: Hämeenlinna, e. 1. 1966, leg. Valkeila, "Spilomena exspectata Valk. o*, det. E. Valkeila", prepared genitalia attached to the pin, GP039 $1982[\mathrm{H}$. Dollfuss] (DAZH).

Paratypes. Finland, Ab: Rymättylä, 3.7.1971 1오, leg. A. K. Merisuo, "Spilomena exspectata Valk. \& Merisuo det. 1971”(DAZH), N: Kirkkonummi (6653:354), 25.7.1991 1우, leg. M. Koponen (DAZH). Ta: Janakkala, 6755:369, on leaves of Populus tremula L. x tremuloides Michx., 9.7.1999 19, 29.7.1999 1 9 ; 6758:372, 7.7.1997 1 ; Janakkala, Harviala (6762:369), 6.8.1976 1이, leg. V. Vikberg (VVPC); Hämeenlinna, 12.7.1958 1ㅇ, leg. Valkeila, "Spilomena exspectata Valkeila, det. E. Valkeila; 26.8.1965 1ㅇ, leg. Valkeila, "Spilomena exspectata Valk., det. E. Valkeila" (DAZH); Hämeenlinna (676:36), 29.6.1976 10 , leg. V. Vikberg, "Spilomena exspectata Valk, ơ, det. E. Valkeila 1976" (VVPC); Hämeenlinna (676:36), on Pastinaca sativa, 24.7.19762\%, 25.7. 1976 5ㅇ, 27.7.1976 1 ㅇ, leg. E. Valkeila (DAZH, MRPC, VVPC); Hämeenlinna, Hätilä (6768:364), 11.8.1976 6오, leg. V. Vikberg (VVPC). Hattula, Parola (677:36), on Pimpinella saxifraga, 3.8.1975 1ㅇ, leg. V. Vikberg (VVPC). Sa: Anttola, on Anthriscus sylvestris, 24.7.1973 1\%, leg. M. Raekunnas, "Spilomena beata Blüthgen 9 , det. E. Valkeila" (MRPC). Tb: Keuruu [as Keuru], 366, 1 \%, leg. Hellén, "troglodytes", "Spilomena exspectata Valk. 우, det. V. Vikberg 1986" (ZMH).

Sweden: Nrk (Ör.): Brickeb.[Brickebacken], July 1956 1 \&, leg. W-en [=Wirén?] (ZIUL). Sdm. (SÖ): Ösmo, Djursnäs, 500 m N Österäng, RN 16177/65365, window trap, June 2229, $199510^{\star}$, leg. J. Abenius (2386), Spilomena beata Blüthgen $ठ$, det. Dollfuss 1996 (JAPC); Stockholm, 15.8.1948 1 우, leg. P. Nuorteva (511; DAZH). Norway: VAy. Marna[r]dal, Lanås, [Laudal, Sveindal gård $=$ farm, Malaise trap] 21.7.6.8.1982 2 ㅇ, leg. A. J. Nilsen (ZMUB).

The new species is close to $S$. beata and differs in both sexes slightly by head form: in $S$.

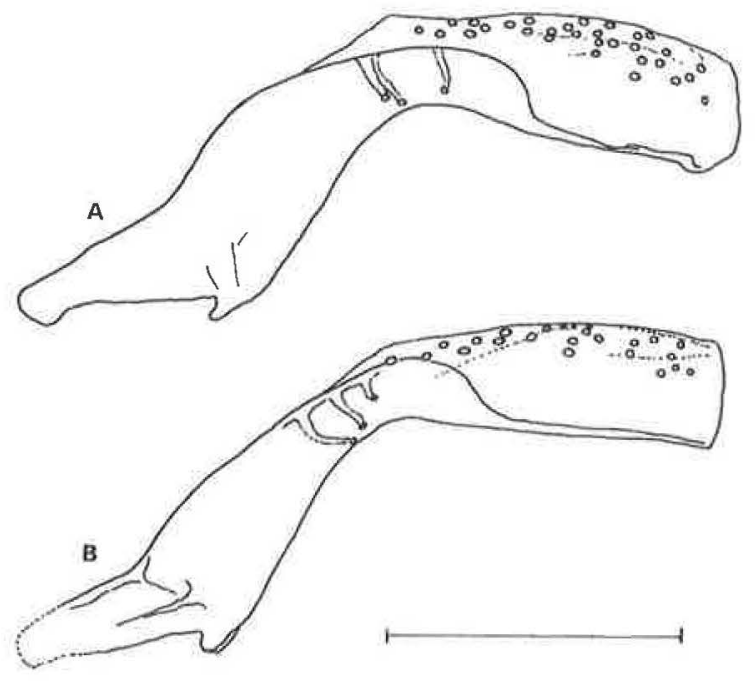

Fig. 12. Penis valve of Spilomena valkeilai sp. $n$. in lateral view. $A=$ the holotype, $B=$ the male from Djursnäs, Ösmo, Sweden. Scale bar $=100 \mu \mathrm{m}$. 
valkeilai the head is less high, relatively broader in anterior view. Body size (mean and maximum) is smaller in $S$. valkeilai. In females I have found no other characters to distinguish the species, e.g. the keels and propodeum surface sculpture vary considerably in both species.

The males differ in colour from Swedish and Norwegian males of $S$. beata; these have flagellum throughout dark brown or blackish; yellow colour on malar space does not extend beyond the level of hind margin of mandible, humeral tubercle has no yellowish margin, and fore coxa and anterior surface of fore femur are blackish.

Austrian males of $S$. beata are more variable. The darkest of them are similar to Norwegian and Swedish males, but the palest have rather pale flagellum or the underside of flagellum is pale brown, yellow area on malar space is extending much beyond base of mandible and anterior surface of fore femur is yellow. None of them had yellowish colour on humeral tubercle. The best distinguishing characters are penis valves (Figs. 12-13). The penis valve of $S$. beata is much larger, its apex is sharp and the sclerotized lower part is differently shaped.

Spilomena valkeilai sp. n. has been reared two times from the nest in the stem of Rubus idaeus in Hämeenlinna by E. Valkeila. I have not seen the reared female mentioned as S. exspectata in Valkeila (1961). In Central Europe S. beata is known to make its nests in holes of Coleoptera, mainly Anobiidae in rotten wood (Blüthgen 1953; Nachtrag as S. "troglodytes", Blüthgen 1960). The temples are about equally strong in both species and do not differ as much as S. enslini (burrowing in stems of Rubus idaeus and Sambucus sp.) and $S$. troglodytes (nests in old galleries of Coleoptera); perhaps differentation in $S$. beata-valkeilai is much younger than in $S$. troglodytes- enslini. However, in Sweden one male of $S$. beata has been reared from stem of Rubus idaeus, and one male was captured on thatched roof (? nest in straw), which is why further observations about the nesting biology of $S$. beata in N. Europe would be very desirable.

\subsection{Key to species of Spilomena of Europe and the Canary Islands}

The latest keys to West-Palaearctic or European Spilomena (Dollfuss 1986, 1991) are good and richly illustrated, but require slight modification because of the changed status of some species. A new amended key is given below to the species of Europe and the Canary Islands.

1. Basal fovea of mesoscutellum longer, pitted. Clypeus often with longitudinal furrow apicomedially 2

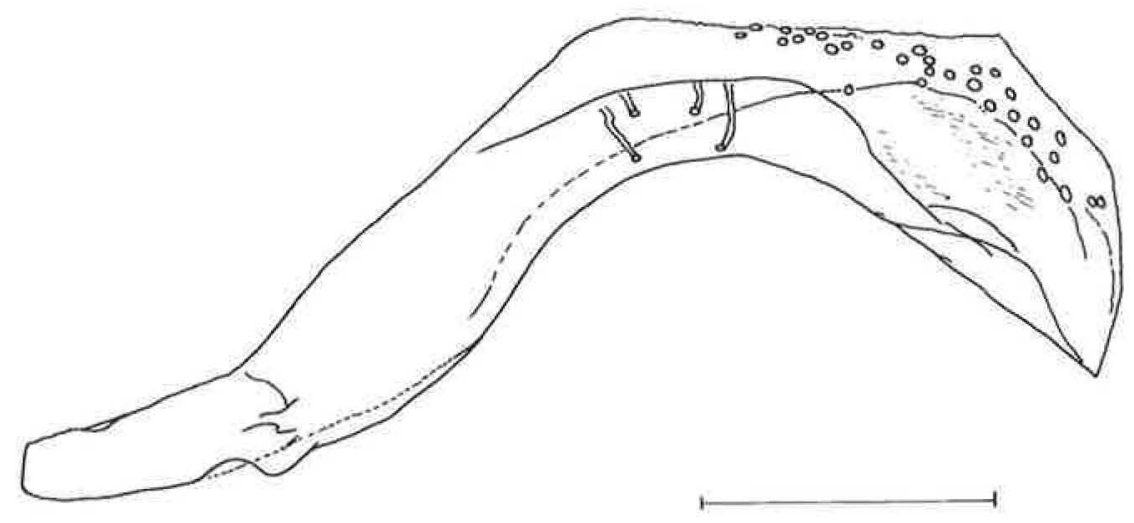

Fig. 13. Penis valve of Spilomena beata Blüthgen in lateral view, a male from Sweden, Nrk. Scale bar $=100 \mathrm{~mm}$. 
- Basal fovea of mesoscutellum shorter, not pitted. Clypeus not furrowed (exceptional specimens of enslini with narrow furrow) ........ 3

2. Mesoscutum posteriorly with few coarse striae, the lateral ones parallel or converging slightly anteriorly. o : POL/OOL 0.52 or larger. $\sigma^{x}$ : pale colouration on clypeus and lateral face more extensive........ curruca (Dahlbom)

- Mesoscutum posteriorly with many fine striae, the lateral ones diverging clearly in anterior direction. o : POL/OOL smaller than 0.52 . $\sigma^{*}$ : pale colouration on clypeus and face less extensive differens Blüthgen

3. Head in anterior view narrow, in female head width/head height index less than 1.0, in male 1.0 or slightly larger. Compound eye 2.2-2.4 as high as wide. Dorsal area of propodeum not margined. $q$ : pygidial area without keels.

- Head in anterior view broader, width/height index larger than 1.0. Compound eye 1.7-2.1 as high as wide 5

4. Only apical margin of mandible reddish brown. Upper frons with weak alutaceous sculpture, with superficial punctures, shining. $o^{*}$ : clypeal excision deep, extends between antennal hollows mocsaryi Kohl

- At least apical 0.25 of mandible reddish brown, more or less infuscate. Upper frons with strong, shagreened microsculpture, thickly punctate, mat. $\sigma^{*}$ : clypeal excision shallow .. punctatissima Blüthgen

5. Sensory seta between median and lateral ocellus ca. $110 \mu \mathrm{m}$ ( ( ) or ca. $75 \mu \mathrm{m}$ ( ( ) long. Dorsal area of propodeum not margined. POL/ OOL $0.46-0.49(\% ; n=4)$ or $0.50\left(o^{*} ; n=1\right)$. $ᄋ$ : clypeus with slight emargination canariensis Blüthgen

- Sensory seta between median and lateral ocellus ca. $50 \mu \mathrm{m}$ long or less..... .. 6

6. POL/OOL 0.28-0.45. Upper frons with shallow microsculpture, sparsely punctured, shining. + : temples often strongly developed .... enslini Blüthgen

- POL/OOL 0.48-0.77 .. 7

7. Dorsal area of propodeum sharply margined laterally and posteriorly. $\circ$ : pygidial area without keels. $\sigma^{x}$ : spur of mesotibia weak, short. Flagellomeres not thickened 8
- Dorsal area of propodeum not margined or weakly margined only laterally. $q$ : pygidial area with keels. o': spur of mesotibia normal. Flagellomeres thickened, moniliform. ......... troglodytes (Vander Linden) (= vagans Blüthgen)

8. Head relatively higher, width/height usually less than 1.09 ( + ) or $1.12\left(\sigma^{*}\right)$. Penis valve with acute apex. Larger species: length of fore wing of female 2.0-2.5 mm (from apex of tegula to apex of wing), head width of female 0.74$0.91 \mathrm{~mm}$.............................. beata Blüthgen

- Head relatively wider, width/heigth usually 1.10 or more ( 9 ), 1.14 or more ( $\left.\sigma^{\star}\right)$. Penis valve with truncate or rounded apex. Smaller species: fore wing of female 2.1-2.25 mm, head width $0.75-0.82 \mathrm{~mm}$. valkeilai $\mathrm{sp} . \mathrm{n}$.

Specimens of Spilomena from Central and South Europe and the Canary Islands studied for this paper:

S. curruca: Austria, Niederösterreich, Piesting, 20.5.1868 1\%, coll. Tschek; Rosenau bei Zwettl, 16.8.1976 1\%, leg. M. Fischer (NHMW); Kärnten, SW Pirker Kogel, Krumpendorf, 400-500 m, 11.6.1977 1ㅇ, leg. M. Fischer (NHMW); Steiermark, 1 km S Furtner Teich, Mariahof, 900-940 m, 8.7.1971 1 +; Gragger-Schlucht SW Neumarkt, 850-900m, 10.7.1971 1 ; ; Zeutschach, 14.7.1971 19; S Hitzmannsdorf bei Mühlen, 950 m, 23.7.1971 3\%; between Furtner Teich and Zeutschach, $950 \mathrm{~m}, 27.7 .19711$ 우 $0.5 \mathrm{~km}$ S Huben, $1200 \mathrm{~m}$, 4.7.1973 $1 \delta^{*}$; Mariahof, Grasluppteich W Neumarkt, $900 \mathrm{~m}$, 14.8.1973 1 \% ; Mariahof, Vockenberg near Furtner Teich, 890 m, 7.7.1975 1 \% , all leg. M. Fischer (NHMW); Tirol, Ötztal, Längenfeld, Fischbachtal, $1250 \mathrm{~m}, 14.6 .19711 \sigma^{7}$; Hoher Nachtberg, NE slope of Ötztal, $2.5 \mathrm{~km}$ S Sölden, $1500 \mathrm{~m}$, 13.7.1974 10, leg. M. Fischer (NHMW). Poland, Tatra National Park, Dolina Bialego, $2 \mathrm{~km} \mathrm{~S}$ Zakopane, $1050 \mathrm{~m}$, 8.7.1968 19; Dolina ku Dziurze, 900-950 m, 6.7.1972 1 $\sigma^{7}$ (the holotype of $S$. pulawskii), leg. M. Fischer (NHMW). According to the information of Dr. S. Schödl these are all the specimens of the species in coll. NHMW.

S. differens: Austria, Niederösterreich, Sperkenthal bei Marbach im Felde, 17.8.76 1 9 , leg. M. Fischer (NHMW). Kärnten, Hüttenberg-Zosen, 800-900 m, 11.8.1973 20 19; Lölling, $6 \mathrm{~km}$ ESE Hüttenberg, 1050-1.200 m, 4.8.1977 1 శ*; St. Martin am Silberberg, $950 \mathrm{~m}, 10.8 .19731 \mathrm{o}^{\star}$, leg. M. Fischer (NHMW). Steiermark, Admont, Klosterkogel between Schloss Röthelstein and Milcheben, 900-1200 m, 21.7.1970 $1 \mathrm{~d}^{\prime}$; Schloss Röthelstein bei Admont, $1000 \mathrm{~m}, 12.7 .19701{ }^{\prime}$; Falkenstein, Fischbach, $800 \mathrm{~m}, 14.8 .197410^{*}$; Fischbach, Falkenstein Obenluger, $950 \mathrm{~m}, 5.8 .19741$; 950-1000 m, 6.8.1974 1; $900 \mathrm{~m}, 7.8 .19741 \% ; 1000 \mathrm{~m}, 15.8 .19741$ 웅 Gragger-Schlucht SW Neumarkt, $900-1000 \mathrm{~m}, 10.7 .19711{ }^{\circ}$; 850-900 m, 10.7.1972 1\% 1우 Kalkberg, St. Blasen, Poduler Teich, $1050 \mathrm{~m}, 21.7 .19753$ \% ; Mariahof, NE Furtner Teich, $890 \mathrm{~m}, 13.8 .19691 \%$; 870-890 m, 2.7.1971 20; Mariahof, Furtner Teich, $880 \mathrm{~m}, 18.8 .19691$ \% ; Mariahof, Vockenberg, 900 m, 3.8.1969 1웅 Vockenberg, Furtner Teich, 900 m, 

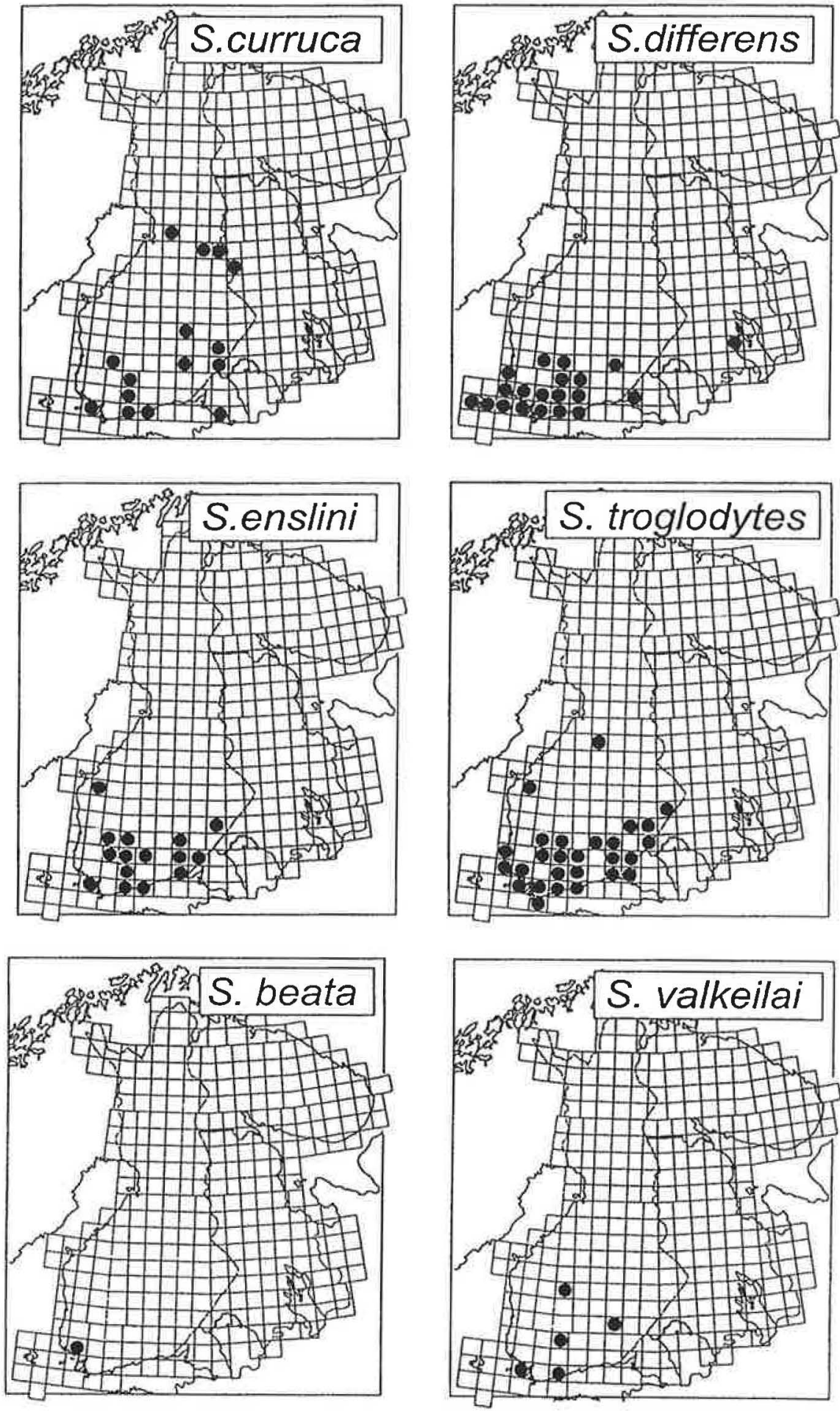

Figs. 14-19. Distribution of Spilomena curruca (Dahlbom), S. differens Blüthgen, S. enslini Blüthgen, S. troglodytes (Vander Linden), S. beata Blüthgen and S. valkeilai sp. n. in Eastern Fennoscandia, the European UTM-map. 
Kondopoga (leg. \& coll. A. Humala, Petrozavodsk).

The Finnish and Russian localities are presented in Fig. 15. This is the only Finnish species known to occur in the Åland/Ahvenanmaa islands. No specimen was examined from the province $\mathrm{Ka}$; Hellén (1954) reported species from Ka: Viipuri, but the locality is in Russia. Thus Ka reported by Lomholdt $(1975,1976)$ should probably be deleted so far from the distribution area of the species in Finland.

Dates of captures in Finland range: males from 15 June (Janakkala 1961) to 16 August (Vanaja 1965); females from 17 June (Tampere 1958) to 4 September (Nurmijärvi 1987). One female from Tampere, 1.7.1953, leg. Th. Grönblom is labelled "Anobium rufipes".

Estonia: Luig (1993) reported one female from Saaremaa, Viidumäe State Nature Reserve, captured on 8 Aug 1990.

\section{Spilomena enslini Blüthgen}

Norway: Not recorded from Norway by Lomholdt (1975-1976). The species was reared from a nest in a stem of Rubus idaeus in AK: Oslo, Hovedøya in April 1989 (2 males 9 females, leg. \& det. A. Fjeldså (ZMUB). In the material collected by Malaise traps in 1991-1998 (coll. Lars Ove Hansen and Norwegian Forest Institute, Ås) 10 males and 26 females were present, the collecting localities are: AK: Bærum; Sørum; Asker; Oslo. Bø: Drammen; Hole; Hurum; Røyken. Bv: Rollag. VE: Borre (sweep-net). TEi: Notodden.

Sweden: Lomholdt (1975-1976) recorded the species from Sm., Öl., Ög., Vg., Nrk., Upl. and Gstr. Nilsson (1992) added Vstm. I have studied 4 males and 11 females from Sk., Sm., Vg., Nrk. and Upl. One male and 3 females of them were reared from a stem of Rubus idaeus (Upl., Uppsala, Sunnersta vid Fyrisån in 1996, leg. S. Hellqvist).

Denmark: nests in Sambucus only found in NEZ, Brede (Lomholdt 1975).

Finland: Blüthgen (1953) described the species based partly on Finnish specimens. Hellén (1954) added some new localities. Valkeila (1957) reared the species from stems of Rubus idaeus $\mathrm{L}$. and Sambucus racemosa L., added four new lo- calities and described the biology of the species: nest constructing and reared specialized parasitoids: Neorhacodes enslini (Ruschka) (Ichneumonidae), Lonchetron fennicum Graham, Kaleva livida Graham (Pteromalidae) and an ubiquitous parasitoid Macroneura vesicularis (Retzius) (Eupelmidae) as Eupelmella vesicularis . Most Finnish specimens in the collections have been reared from the nests in stems of Rubus and Sambucus. Only 8 males and 37 females have been captured in nature, whereas 177 males and 325 females have been reared, most of them by Erkki Valkeila. I have reared the species from stems of Rubus idaeus in Karkkila (April 1975), Janakkala (April 1975; also 2 males and 7 females of Lonchetron fennicum, and one male and female of Kaleva livida emerged) and Tampere (May 1965; also one female of Neorhacodes enslini emerged and a dead female of Lonchetron fennicum was found in the nest).

Finnish localities. Ab: Perniö; Lohja; Karkkila. N: Nurmijärvi; Porvoo. Ta: Riihimäki; Hausjärvi; Janakkala; Vanaja; Hämeenlinna; Hattula; Kalvola; Urjala; Lammi; Eräjärvi; Tampere. Sa: Ristiina; Mäntyharju; Lappee; Luumäki; Taipalsaari; Punkaharju. Oa. Kurikka. Kb: Kesälahti.

The distribution of the species is mapped in Fig. 16. The northernmost locality is Kurikka, 6965:252 (one female on 8 July 1999, M. Koponen leg.).

Dates of capture in Finland for males range from 27 June (Hämeenlinna 1966) to 3 August (Janakkala 1998), for females from 20 June (Vanaja 1964) to 15 September (Hämeenlinna 1974).

\section{Spilomena troglodytes (Vander Linden) (syn. S. vagans Bluithgen)}

Norway: According to Lomholdt (1975) as S. vagans only known from AAy, "Aurdal" (one female examined in coll. ZM, Oslo is labelled AAy. Arendal). In coll. ZMUB the species was represented with 23 males and 27 females from $\varnothing$ : [Moss], Jeløy. AK: Bærum; Oslo. VE: Tjøme. TEy: Bamble. VAy: Mandal; Marnardal. Two females of them were reared in Tjøme, Kolabekkilen from galls of Biorrhiza pallida (Olivier) on Quercus robur, collected on 12.8.1972, emerged in May 1973 by A. Fjeldså. In the material collected with 
Malaise traps (in coll. Lars Ove Hansen) there were 16 males and 124 females from AK: Asker; Bærum; Oslo; Ås. Bø: Drammen; Nedre Eiker; Hole; Hurum; Kongsberg; Røyken. Bv: Rollag. VE: Borre; Våle. TEy: Drangedal; Krager $\varnothing$. TEi: Notodden. S. differens and S. troglodytes are two most frequent species in southern Norway.

One female from Drammen, Underlia, June 1994 has yellow colouring on left side of face, otherwise it appears to be a normal female.

Sweden: Lomholdt (1975-1976) reported the species (with $S$. vagans included) from 12 provinces from Sk. in the south to Gstr. and Hls. in the north. Nilsson (1992) added Vstm. I have examined 5 males and 9 females from Sk., Hall., Sm., G. Sand., Ög., Vg., Dlr., Gstr. and Vb. The males from Hall.: Väderö, 20.7.1950 and G. Sandön, 1946, leg. A. Jansson were misidentified as $S$. exspectata by O. Lomholdt, so these two provinces should be removed from the distribution of $S$. beata (syn. exspectata) and attributed to $S$. troglodytes. The northernmost specimen is a female from Vb.: Umeå sn., Baggböle, 2 July 1993, leg. $\mathrm{S}$. Hellqvist. Now the species is known in 16 provinces.

Denmark: both colour forms known from Denmark, but they are not common (Lomholdt 1975-1976). I have examined only one male from EJ: Glatved, 12 km S Grenå, 8.7.1998, leg. R. Danielsson.

Finland: Grönblom (1912) first reported $S$. troglodytes from Finland. Pulkkinen (1931) treated $S$. troglodytes as the only species in S. Finland. Blithgen (1953) described the pale form of the species (vagans) as a new species and based this partly on Finnish specimens. Hellén (1954) and Valkeila (1957) added many new localities. Valkeila (1957) gave notes on the biology of the species and described the eonymph. The most frequent species in Finland is represented in collections with 324 males and 1111 females, dark forms are scarce.

Finnish localities. Ab. Rymättylä; Turku; Littoinen; Uskela; Dragsfjärd; Finby; Karjalohja; Vihti; Karkkila. N: Hanko; Espoo; Helsinki; Nurmijärvi; Pernaja; Porvoo; Porvoon mlk. Ka: Virolahti. St: Rauman mlk.; Suoniemi. Ta: Riihimäki; Pirkkala; Nokia; Tampere; Kangasala; Pälkäne; Luopioinen; Hämeenlinna; Aulanko; Vanaja; Jana- kkala; Renko; Hattula; Kalvola, Pirttikoski; Lammi; Nastola. Sa: Joutsa; Ristiina; Mikkelin mlk.; Luumäki; Joutseno; Taipalsaari, Kylänniemi; Rantasalmi. Kl: Parikkala. Kb: Kitee; Tohmajärvi. Oa: Ilmajoki, 6972:274, 7.7.1999 1ơ, leg. M. Koponen. Om: Kestilä, 7135:461, 29.6.1978 $1 \sigma^{\star}$, leg. M. Koponen. - Outside of the present area of Finland there are six females from Leningrad Province, Vyborg ("Viipuri", leg. Linnaniemi).

Dates of capture in Finland are for males from 9 June (Hämeenlinna 1978) to 31 July (Janakkala 1997) and for females from 11 June (Hämeenlinna 1978) to 20 September (Janakkala 1998). There are few reared specimens of the species: Espoo (667:37), 4 females were reared from a dry fence stake of Picea abies in 1983-1984 by M. Pulkkinen. Kangasala, one male was reared from a stem of Alnus sp. on 22.6.1944 by Th. Grönblom. Tampere, 22.9.1935 3 females have been labelled "parasite of larva of Anobium emarginatum", leg. A. Saatinen [the larva of anobiid Microbregma emarginata (Duftschmid) bores in the bark of Picea abies L.]. Tampere, Näsinpuisto, 2 males and 11 females were reared from a piece of rotten wood of Aesculus hippocastanum L. with holes and galleries of Anobium rufipes Fabricius in April 1965 by me, a female of Neorhacodes enslini emerged at the same time.

The distribution in E. Fennoscandia is presented in Fig. 17.

Estonia: Luig (1993) reported as S. vagans only very old specimes from Tartu and [Kasaritsa].

\section{Spilomena beata Blüthgen (syn. S. exspectata Valkeila)}

Norway: the species has not been recorded from Norway (Lomholdt 1975-1976). In Norwegian collections it was represented by 4 males and 29 females. The localities are AK: Asker; Baerum; Oslo. Bø: Drammen; Hurum; Kongsberg; Røyken. Bv: Rollag. VE: Nøtterøy; Tjøme; Våle. TEi: Notodden. Most specimens were captured using Malaise traps, but following have exact collecting dates: Drammen, Underlia, 28 May 1997 female, leg. L. O. Hansen; Tjøme, Moutmarka, 8 June 1992 female, leg. L. O. Hansen; Oslo, Tøyen, 11 July 1998 female, leg. L. O. Hansen; Kongs- 
berg, Kongsberg, car-net, 12 Aug. 1996 male, leg. B. Sagvolden; Oslo, Kastellet, 14 Aug. 1888 female, leg. H. Kiaer.

Sweden: S. beata has been reported rather recently from S. Sweden, VS (=Vstm.): Ridön, one male on a thatched roof of a barn (Nilsson 1991). Earlier records (Valkeila 1957, 1961, Lomholdt 1975-1976, Dollfuss 1986) of the species were as S. exspectata. Also Nilsson $(1991,1992)$ gave most of the records as $S$. exspectata (he added Gtl., Upl. and mentioned one female from Vstm.: Solbacken under this name). Lomholdt (19751976) recorded the species from 6 provinces: Sk., Bl., Sm., Nrk., Sdm., and Gstr., [two provinces Hall. and G. Sand. were based on misidentification; see $S$. troglodytes]. I have examined 9 males and 33 females from the same six provinces plus Öl., Upl., Vstm. and $\mathrm{Nb}$. The female from $\mathrm{Nb}$.: Brandö öarna, 29.7.1971, leg. K.-J. Hedqvist is now without a head, its fore wing is $2.35 \mathrm{~mm}$.

The dates of captures for males are from 1 July (Västerång, Ridön 1990) to 30 July (Hille 1959). Females have been collected from 13 June (Dalby 1992; Korsberga 1933) to 29 Aug. (Mönsterås 1954). One male from Upl.: Uppsala, Sunnersta, vid Fyrisån was reared in 1996 from a stem of Rubus idaeus ("kläckt ur hallonskott") by S. Hellqvist.

Denmark: a single female was reported from EJ, Molslaboratoriet as S. exspectata by Lomholdt (1975). I have not seen it.

Finland: Ab: Masku, 8.7.1954, leg. E. Thuneberg (the holotype of $S$. exspectata) is the only known specimen in Finland. The locality is shown in Fig. 18.

Note. Valkeila (1978) reported Spilomena beata from Finland, Sa (=ES): Anttola, 2 females on 24 and 25 July 1973 on the flowers of Anthriscus sylvestris (L.) Hoffm., leg. M. Raekunnas. I examined these specimens and the earlier of them is a female of $S$. valkeilai and the later is $S$. troglodytes (= vagans). Thus, the first record of $S$. beata from Finland was based on a misidentification.

\section{Spilomena valkeilai sp. $\mathbf{n}$.}

Norway: Two females from VAy: Marnardal agree with Finnish specimens. Two more females (VE: Våle, Lang øya and B $\varnothing$ : Drammen, Underlia) are very close to $S$. valkeilai in the measurements of the head, but from the same localities typical specimens of $S$. beata were captured and these females are identified as $S$. beata. No male is known from Norway yet.

Sweden: Only two females from Nrk.: Brickebacken and Sdm./Upl.: Stockholm. Many specimens of $S$. beata have been captured at the first locality. One male from Sdm. confirms the existence of $S$. valkeilai in Sweden.

Finland: At present the species ( 2 males and 25 females) is known from $\mathrm{Ab}, \mathrm{N}, \mathrm{Ta}, \mathrm{Sa}$ and $\mathrm{Tb}$. Lomholdt 1975-1976 reported S. exspectata also from St, but I have not seen any specimens from this province. The female from Tb: Keuruu was reported as $S$. troglodytes by Hellén (1954) and as $S$. exspectata by Vikberg (1986a).

This sixth Finnish species of Spilomena should be added to the latest check list of Finnish aculeate Hymenoptera (Vikberg 1986b) and species names $S$. vagans and $S$. exspectata put into synonyms of $S$. troglodytes and $S$. beata, respectively. Distribution of the species in Finland is shown in Fig. 19.

\section{Discussion}

The composition of the North European fauna of Spilomena is now well known, but there remains much to be done in investigating the distribution of the species further. Especially the areas situated north of the better studied southern provinces require more observation, e.g. in Finland the provinces $\mathrm{Oa}, \mathrm{Tb}, \mathrm{Sb}$ and $\mathrm{Kb}$ and those even further north. But even in southern Finland there are several UTM squares with no recorded species of Spilomena. The collecting activity has been uneven. The faunas of the Karelian Republic (one species of Spilomena) and the Leningrad Province, Russia (three species, each from one locality in the Karelian Isthmus) are badly known; no new records since Hellén (1954) are mentioned by Pulawski (1978). Also the fauna of Estonia (two species) requires further investigation.

Most specimens have been collected in North Europe south of latitude $62^{\circ} \mathrm{N}$. Three species have passed the latidude $63^{\circ} \mathrm{N}$ : $S$. curruca in Norway, Sweden and Finland, $S$. beata in Sweden and $S$. 
troglodytes in Sweden and Finland. The species going furthest north is $S$. curruca which in Sweden has crossed the Polar circle. S. curruca is infrequent everywhere but it occurs also in E. and N. Finland in old-growth forests, e.g. in Kn: Kuhmo, Ulvinsalo and Ypykkävaara. The type locality of $S$. curruca is rather north (a little South of $64^{\circ} \mathrm{N}$ ) also in Norway. In Europe the species has clearly a boreomontane distribution. Based on the distribution in eastern Fennoscandia it seems more probable that the specimens reported from the Russian Far East and the Kurile Islands (Dollfuss 1986) really belong to $S$. curruca and not to $S$. differens. In Austria also most specimens of $S$. differens have been captured high in the mountains but in N. Europe the species has been found rather south only.

Males of Spilomena are distinctly less numerous than females in the collections. The best investigated species in North Europe regarding the sex ratio is $S$. enslini. In Finland 502 specimens have been reared from the nests and 177 of these or 35 percent were males. Among smaller material $(n=45)$, captured in the field in Finland, the percentage of males is 18 , and in Norway amongst specimens $(n=36)$ of $S$. enslini captured by Malaise traps the percentage of males is 28 . In $S$. differens, captured in the field, the percentage of males is 32 in Finland $(n=220), 25$ in Sweden $(n=116)$ and 14 in Norway $(n=136)$. Among $S$. troglodytes captured in the field the percentage of males is 23 in Finland ( $n=1435$ ), 26 in Norway $(n=189)$ but only 11 among specimens collected by Malaise traps $(n=141)$. In specimens of $S$. beata in Sweden $(n=42) 21 \%$, in Norway $(n=33) 12 \%$ are males. Still smaller percentages of males are found in Finland in S. valkeilai $(7 \%$; $n=27)$ and in $S$. curruca (3\%;n=32). If we count all examined N. European specimens of $S$. curruca together, the percentage of males is $4(n=47)$, whereas among C. European specimens $(n=17)$ males constitute $24 \%$. For comparison the percentage of males among Austrian specimens in Dollfuss (1986) was counted with the following result: Spilomena beata 22 ( $n=107), S$. differens 20 ( $n=64 ; 8$ females of $S$. pulawskii mentioned by Dollfuss (1996) subtracted), S. enslini 38 $(n=13), S$. mocsaryi 46 ( $n=131)$, S. punctatissima $14(n=72)$ and $S$. troglodytes $43(n=531)$. In two species the sex ratio appears to be nearly $1: 1$.
Evidently in nature males more easily escape attention than females, and their flight period is shorter than that of females. In Norway the percentages of males among specimens of Spilomena differens, troglodytes and beata collected by Malaise trapping is smaller than among specimens from Finland or Sweden, collected mostly by other methods. The difference could be explained by assuming that Malaise traps catch females more efficiently than males, or the trapping period favoured females or the males are really less frequent in Norway than in Sweden and Finland. It is noteworthy that the males of $S$. curruca are so few in North Europe; but why is difficult to say.

Acknowledgements. I thank warmly Johan Abenius, Anders Albrecht, Roy Danielsson, Arild Fjeldsă, Lars Ove Hansen, Sven Hellqvist, Andrey Humala, Lars- ̊̀ke Janzon, Lita Greve Jensen, Martti Koponen, Nina Laurenne, Göran E. Nilsson, Jonny Perkiömäki, Jan E. Raastad, Martti Raekunnas and Stephan Schödl for the specimens needed for this study. Martti Koponen gave me information from W. Hellén's collecting notebook. Johan Abenius commented the first draft of the manucript in detail and suggested many improvements. Hannu Kangas calculated the $p$ values. Alexey $\mathrm{Zi}-$ novjev gave technical help with the tables and scatter diagrams. Ilari Sääksjärvi informed me about the specimens in the Zoological Museum, University of Turku.

Addendum. Spilomena beata Bluethgen. Finland, Al: Finström, Husö-Björkö (670:10), 5.7.1984 one female, V. Vikberg leg. The length of forewing is $2.35 \mathrm{~mm}, \mathrm{HW} / \mathrm{HH}$ 1.06, HW/FH 1.26. This is the first specimen in the Aland islands and the second in Finland.

\section{References}

Blüthgen, P. 1953: Alte und neue paläarktische SpilomenaArten (Hym. Sphecidae), - Opusc. Entomol. 18(2-3): 160-179.

Blüthgen, P. 1960: Zur Verbreitung und Lebensweise der europäischen Spilomena-Arten (Hym. Sphecid.). Nachr.bl. Bayr. Ent. 9 (1): 1-5.

Dahlbom, A. G. 1843: Hymenoptera Europaea praecipue borealia. Fascic. I. - 172 pp., Lundbergiana, Lund.

Dollfuss, H. 1983: The taxonomic value of male genitalia of Spilomena Shuckard, 1838, from the palearctic region (excl. Japan) (Hymenoptera, Sphecidae). — Entomofauna 4(22): 349-370.

Dollfuss, H. 1986: Eine Revision der Gattung Spilomena Shuckard der westlichen und zentralen paläarktischen Region (Hymenoptera, Sphecidae). - Ann. Naturhist. Mus. Wien 88/89 B: 481-510.

Dollfuss, H. 1991: Bestimmungsschlüssel der Grabwespen 
Nord- und Zentraleuropas (Hymenoptera, Sphecidae) mit speziellen Angaben zur Grabwespenfauna Österreichs. - Staphia 24: 1-247.

Dollfuss, H. 1996: Das Weibchen von Spilomena pulawskii Dollfuss 1983 gefunden (Hymenoptera, Sphecidae). Linzer biol. Beitr. 28(2): 897-898.

Goulet, H. \& Huber, J. T. (eds.) 1993: Hymenoptera of the world: an identification guide to families. - i-vii, 1668 pp., Research Branch, Agriculture Canada, Ottawa, Ontario.

Grönblom, T. 1912: Tvă för Finland nya rofsteklar. — Medd. Soc. Fauna Flora Fennica 38: 72-73.

Hansen, L. O. 1995: Aculeata of Norway. 1. Bethylidae (Hym., Apocrita). — Fauna norv. Ser. B 42: 43-48.

Hellén, W. 1954: Die Spilomena-Arten Finnlands (Hym., Sphec.). - Notulae Entomol. 34: 60-63.

Lomholdt, O. 1975: The Sphecidac (Hymenoptera) of Fennoscandia and Denmark. - Fauna entomol. scandinavica 4, part 1: 1-224.

Lomholdt, O. 1976: The Sphecidae (Hymenoptera) of Fennoscandia and Denmark. - Fauna entomol. scandinavica 4, part 2: 225-452.

Luig, J. 1993: The distribution and phenology of the Sphecoidea (Hymenoptera, Aculeata) species in Estonia. 1. The families Ampulicidae, Sphecidae, Pemphredonidae, Astatidae, and Larridae. - Proc. Estonian Acad. Sci. Biol. 42 (1): 39-54.

Nilsson, G. E. 1991: The wasp and bee fauna of the Ridö archipelago in lake Mälaren, Sweden (Hymenoptera, Aculeata). -- Entomol. Tidskr. 112: 79-92.

Nilsson, G. E. 1992: Nya fynd av gaddsteklar i Sverige. (New records of Hymenoptera Aculeata from Sweden). - Ent. Tidski: 113(4): 53-57. (In Swedish, with English summary).

Pulawski, V. V. 1978: Sphecoidea, In: Tobias, V. I. (ed.): Keys for the identification of the insects of the European USSR, vol.3, Hymenoptera, part 1. - Leningrad Nauka, 584 pp. (In Russian)

Pulkkinen, A. 1931: Myrkkypistiäiset, Hymenoptera aculeata. 1. Petopistiäiset, Sphecidae. - Suomen eläimet, Animalia fennica 1: 1-168.

Valkeila, E. 1957: Mitteilungen über die nordeuropäischen Spilomena-Arten (Hym., Sphecoidea). - Annales Entomol. Fennici 23(4): 163-178.

Valkeila, E. 1961: Beiträge zur Kenntnis der nordeuropäischen Raubwespen (Hym., Sphecoidea). - Annales Entomol. Fennici 27(3): 141-146.

Valkeila, E. 1978: Spilomena beata Blüthgen (Sphecidae: Pemphredoninae) löydetty Suomesta. - Notulae Entomol. 58 (4): 176. (In Finnish)

Vikberg, V. 1986a: Notes on some Finnish taxa of Hymenoptera Apocrita Aculeata. - Notulae Entomol. 66: 61-64.

Vikberg, V. 1986b: A checklist of aculeate Hymenoptera of Finland (Hymenoptera, Apocrita Aculeata). - Notulae Entomol. 66: 65-85. 